Maja Šabec

\title{
Sejdalija Gušić, Edina Spahić, Cecilia Prenz Kopušar (ur.): Laura Papo Bohoreta: rukopisi
}

Sarajevo: Historijski arhiv Sarajevo, Filozofski fakultet u Sarajevu, 2015-2017, 3 knjige: 232 str., 334 str. in 332 str.

Med letoma 2015 in 2017, ob 450. obletnici prihoda Sefardov v Bosno, je čedalje obsežnejšo bibliografijo o sefardskih študijah na področju Balkana obogatila trilogija, ki bo nedvomno razveselila ne le krog izvedencev sefardskih študij, temveč tudi znanstvenike $\mathrm{z}$ drugih področij ter širše domače in tuje bralstvo. Tri knjige $\mathrm{z}$ naslovom Laura Papo Bohoreta: rukopisi, objavljene zaporedoma v letih 2015, 2016 in 2017, omogočajo dostop do vseh rokopisov najzaslužnejše varuhinje jezika in kulture bosanskih Sefardov Laure Papo Bohoreta (1891-1941), katere zapuščino od leta 1961 hrani Zgodovinski arhiv v Sarajevu.

Po zaslugi odkritij priznanih strokovnjakov s področja nekdanje Jugoslavije in iz tujine se je zanimanje za ta fond neprecenljive kulturne, zgodovinske in literarne vrednosti ter njegovo avtorico $\mathrm{v}$ zadnjih desetletjih močno povečalo. Laura Papo je bila izjemna ženska, nosilka in glasnica pristnega sefardskega izročila ter hkrati pogumna zagovornica sodobne misli in napredka na vseh področjih zasebnega in javnega življenja. Odločno se je zavzemala za izboljšanje položaja žensk v družinskem krogu in družbi ter si s tem prislužila naziv prve feministke na ozemlju današnje Bosne, njena ostra razmišljanja o delovnih pogojih, krizi in družbeni ureditvi pa izražajo jasna socialistična načela. Sarajevčanka in kozmopolitka hkrati, intelektualka, poliglotka, prevajalka, pisateljica ter zbirateljica ustne in pisne književnosti je vse svoje življenje posvetila ohranjanju in prenašanju védenja Sefardov in védenja o njih na prihodnje rodove. Vse njeno delo, napisano v judovskošpanskem (ladino) jeziku in v latinski pisavi, ki ga lahko zdaj listamo v obliki faksimilov, priča o njenem plemenitem nesebičnem prizadevanju, da bi se ohranil individualni in kolektivni spomin skupnosti, ki ji je pripadala.

Objava rokopisov je rezultat projekta »Digitalizacija in objava osebnega fonda Laure Papo Bohoreta« v sodelovanju Zgodovinskega arhiva Sarajevo in Univerze v Sarajevu ter ob podpori španskega veleposlaništva v Bosni in Hercegovini. Naloga sodelavcev je bila digitalizirati celotno dokumentarno gradivo ter že objavljena in neobjavljena besedila razdeliti $\mathrm{v}$ tri zvezke ter jih opremiti s spremnimi besedili. (Predviden je tudi dostop do digitaliziranih verzij prek spletne strani arhiva.) Treba 
je omeniti, sledeč besedam Ane Cecilie Prenz Kopušar, da je dal pobudo za ta korak eden najbolj predanih raziskovalcev vsega, kar je povezano z življenjem in kulturnim delovanjem sarajevske sefardske skupnosti, filolog in literarni kritik Muhamed Nezirović, zato je publikacija med drugim tudi poklon pokojnemu učitelju.

Zaradi raznovrstnosti zapisov po eni strani - od dramskih, pripovednih in esejističnih besedil ter različno dolgih pesmi, prek osnutkov in kratkih besedil do prevodov in transkripcij ustnega izročila - ter hkrati enotnosti misli, ki jih povezuje, je razdelitev na tri sklope, ki ustrezajo trem knjigam, povsem praktične narave in združuje različna merila: zvrst (gledališče, pripovedništvo, esej, poezija), tematiko (izročilo in običaji, zgodovina, družbena angažiranost) in kronologijo (ohranjena dela je avtorica napisala med letoma 1927 in 1936).

V prvi knjigi so zbrana štiri dramska dela s tematiko ljudskih običajev: Ožos mios in tri enodejanke: Avia de Ser, La pasiensia vale mučo in Tiempos pasados. Tudi druga knjiga je posvečena gledališču, tokrat s socialno tematiko: Shuegra ni de baro buena, Hermandat in Esterka, v tretji pa so zelo različna besedila: dva eseja (La mujer sefardí de Bosna in Hecho hechizo), štiri pesmi (Al ocasion del jubileo de combate, lavoro y suceso, Huanita, Madres in Violetas), trije kratki komadi (La molinera y la karvonera, Dotas in Davičon el hamal), prevod pesmi Flor a murčada hrvaškega avtorja Gustava Krkleca v judovsko španščino, kratko besedilo Depués de las hadras, romance, ki jih je zbrala Bohoreta, skupaj z Amadi romance espagnole du moyen âge, eno pismo in trije portreti (Toja Rahelona de Sason, Tija Merkada de Jahilo Finci in La paparoza de tijo Kako Monteira).

Uvodne študije, ki spremljajo faksimile, so objavljene v dveh jezikih, v bosanščini in kastiljščini. Prispevali so jih direktor (do leta 2016) Arhiva Sarajeva Sejdalija Gušić ter raziskovalki Laure Papo Bohoreta Edina Spahić z Univerze v Sarajevu in Ana Cecilia Prenz Kopušar z Univerze v Trstu. Edina Spahić najprej na kratko oriše značilnosti judovske španščine, ki so jo govorili v Bosni, in sefardske kulture, nato pa se osredini na življenje sarajevske avtorice in njen pomen za poznavanje bosanske sefardske skupnosti. Ana Cecilia Prenz Kopušar pa predstavi vsako od reproduciranih besedil in pri tem izpostavi teme, ki jih Bohoreta obravnava v malodane vseh zapisih - ohranjanje sefardskega izročila, lik ženske v družini in družbi, izobrazba žensk in njihovo vključevanje v delo, družbena angažiranost in univerzalne vrednote. Poudari pisateljičino prizadevanje, da bi občinstvu sporočila prenesla čim bolj neposredno, brez velikih umetniških pretenzij, a literarna vrednost v njenem pisanju zaradi tega nikakor ne umanjka, nasprotno: njena pripovedna veščost $\mathrm{v}$ kombinaciji $\mathrm{z}$ rabo gledaliških sredstev se zaradi iskrenosti, spontanosti in prirojene občutljivosti, s katerimi se loteva snovi, zlije v edinstveno in zgledno osebno poetiko. 
Zdaj ko so rokopisi dosegljivi raziskovalcem najrazličnejših znanstvenih področij, je mogoče pričakovati odkritja, ki bodo dopolnila védenje o vidikih, ki so že bili predmet številnih študij (na primer najbolj emblematično, najbolj raziskano in edino doslej prevedeno delo La mujer sefardí de Bosna, romance in gledališka dela), in druga, ki bodo približala pričakovano jezikovno, literarno, zgodovinsko in kulturno bogastvo manj poznanih besedil (pesmi, kratkih spisov in portretov). Prvi korak bi moral biti čimprejšnja kritična izdaja celotnega opusa s transkripcijo in prevodom $v$ bosanščinosrbščino-hrvaščino, kar je nujni pogoj, da bodo lahko do tega zaklada dostopali tudi raziskovalci, ki ne obvladajo nujno judovske španščine.

Kdor bo segel po delu Laure Papo Bohoreta, se bo lahko prepričal, da je bil njen namen veliko daljnosežnejši kot zgolj prikazati sefardsko folkloro. $S$ tem ko je literarno upodobila življenje skupnosti, ki je bila zaradi svoje zaprtosti od nekdaj ovita v pajčolan skrivnosti, je osebne izkušnje njenih pripadnikov prenesla na univerzalno raven. Nemara je največji čar njenih zgodb v tem, da izražajo neopredeljivo »bosansko rahločutnost «, ki je, daleč od tega, da bi se zazirala le v svoj svet, zmožna stopiti v dušo drugega in jo osvojiti. $\mathrm{V}$ tem pogledu je Bohoretina literatura zaslužna za obogatitev poznavanja edinstvene in zapletene (več)kulturne tradicije tega dela Balkana, natančneje, Sarajeva, mesta, ki ga je tako ljubila in katerega tok skozi zgodovino ne bi mogel biti bolj čaroben, buren in tragičen. 